\title{
EDUKASI TENTANG CINTA LINGKUNGAN BERSAMA KANG PISMAN DESA CANGKUANG KECAMATAN RANCAEKEK KABUPATEN BANDUNG JAWA BARAT
}

\author{
Neti Juniarti, Desy Indra Yani dan Citra Windani Mambang Sari \\ Fakultas Keperawatan Universitas Padjadjaran \\ E-mail: neti.juniarti@unpad.ac.id
}

\begin{abstract}
ABSTRAK. Air bersih merupakan salah satu kebutuhan dasar manusia yang sangat penting dalam menjamin keberlangsungan hidup semua makhluk termasuk manusia. Salah satu sumber air bagi masyarakat di Jawa Barat adalah sungai Citarum. Untuk meningkatkan keberhasilan upaya promosi kesehatan khususnya perilaku hidup bersih dan sehat (PHBS) maka dapat dilakukan dengan mengintegrasikan konsep setting, ekosistem, air dan kesehatan melalui model promosi kesehatan ekologikal yang berfokus pada system serta perubahan dan perkembangan seluruh organisasi. Pendekatan terintegrasi ini dapat melibatkan berbagai sektor dan organisasi dalam masyarakat dengan menggunakan proses kemitraan antara pihak akademisi, pelayanan kesehatan dan pemerintah daerah serta organisasi kemasyarakatan lainnya. Kegiatan pengabdian bertujuan memberikan edukasi yang diperlukan kepada anak-anak sejak dini desa cangkuang mengenai pentingnya kebersihan dan cinta lingkungan. Kegiatan pertama yaitu dilakukannya pre test menggunakan flashcard berupa gambar perilaku baik dan buruk tentang sampah. Kegiatan kedua yaitu edukasi tentang CILUNG KANGPISMAN (Cintai Lingkungan dengan Kurangi, Pisahkan dan Manfaatkan), pemanfaatan sampah dan perilaku baik dan buruk tentang sampah. Selanjutnya dilakukan kegiatan mewarnai gambar tentang lingkungan yang bersih. Kegiatan ketiga adalah post test dengan menggunakan flashcard berupa gambar perilaku baik dan buruk tentang sampah. Peserta yang mengikuti kegiatan ini yaitu sebanyak 30 anak. Hasil pre test dan post test sebagian besar menjawab benar. Implikasi dari pengabdian adalah dengan adanya edukasi tentang Kang Pisman, anak-anak dapat mengetahui pentingnya kebersihan dan cinta lingkungan sejak dini. Selain itu, anak-anak dapat menyampaikan edukasi yang didapat untuk diberitahukan ke orang tua dan keluarga terdekat.
\end{abstract}

Kata kunci: edukasi; kang pisman; lingkungan

\begin{abstract}
Clean water is one of the basic human needs that is very important in ensuring the survival of all creatures including humans. One source of water for people in West Java is the Citarum river. To increase the success of health promotion efforts, especially clean and healthy living behavior (PHBS), it can be done by integrating the concepts of setting, ecosystem, water and health through an ecological health promotion model that focuses on systems and changes and developments throughout the organization. This integrated approach can involve various sectors and organizations in society by using a partnership process between academics, health services and local government and other social organizations. Community service aims to provide education to children from early childhood in the village of Cangkuang about the importance of cleanliness and love for the environment. The first activity is to do a pre-test using a flashcard in the form of good and bad behavior pictures about waste. The second activity is education about CILUNG KANGPISMAN (Cintai Lingkungan dengan Kurangi, Pisahkan dan Manfaatkan), waste utilization and good and bad behavior about waste. Furthermore, coloring activities on clean environment are carried out. The third activity is a post test using a flashcard in the form of good and bad behavior pictures about waste. Thirty children participated in this activity. Most of the pre test and post test results answered correctly. The implication of devotion is that with education about Kang Pisman, children can know the importance of cleanliness and love for the environment early on. In addition, children can convey the education they have received to notify their parents and immediate family.
\end{abstract}

Keywords: education; environment; kang pisman

\section{PENDAHULUAN}

Air bersih merupakan salah satu kebutuhan dasar manusia yang sangat penting dalam menjamin keberlangsungan hidup semua makhluk termasuk manusia. Salah satu sumber air bagi masyarakat di Jawa Barat adalah dari sungai Citarum sepanjang 297 $\mathrm{km}$ yang merupakan sungai terbesar dan terpanjang di Jawa Barat. Kondisi lingkungan dan kualitas air di sungai Citarum terus menurun sejak 20 tahun terakhir ini di berbagai daerah aliran sungai dan seringkali menyebabkan banjir (Cita Citarum, 2014). Salah satu faktor yang menyebabkan penurunan kualitas air sungai yaitu perilaku hidup bersih dan sehat masyarakat yang seringkali membuang sampah ke sungai, membuang limbah rumah tangga ke aliran sungai dan menggunakan sungai sebagai sarana mandi, cuci dan kakus (Widyasari, 2017). Oleh karena itu, perilaku hidup bersih dan sehat masyarakat pada tatanan rumah tangga sangat penting untuk dilakukan dalam rangka mengurangi pencemaran sungai Citarum yang bersumber dari sampah dan limbah rumah tangga.

Pemerintah Indonesia sudah mengeluarkan kebijakan tentang pembinaan perilaku hidup bersih dan sehat pada tatanan rumah tangga sejak tahun 2011 (Kementerian Kesehatan RI, 2011), akan tetapi perilaku hidup bersih dan sehat masyarakat hanya mencapai 38,7\% pada tahun 2007 dan perilaku sehat ini menurun menjadi 32,2\% pada tahun 2013 (Badan 
Litbang Kesehatan, 2013; Litbangkes, 2007). Pada tahun 2018, perilaku kesehatan masyarakat dalam membuang sampah dan mengelola air limbah rumah tangga juga masih rendah dimana 36,8\% masyarakat yang mengolah limbah dengan benar dan hanya 18,8\% yang membuang limbah kamar mandi/WC ke tempat tertutup (Badan Litbang Kesehatan, 2018). Rendahnya perilaku hidup bersih dan sehat masyarakat ini merupakan tantangan yang harus segera ditangani karena air sungai yang tercemar sangat berisiko menimbulkan masalah kesehatan yang pada akhirnya dapat menurunkan kualitas hidup masyarakat.

Hasil penelitian Halder and Islam (2015) menunjukkan bahwa sungai yang tercemar dapat menyebabkan penyakit kulit, diare, disentri, gangguan pernapasan, anemia dan komplikasi pada saat ibu melahirkan. Selain itu, penyakit Yellow fever, kolera, demam berdarah, malaria dan penyakit lain juga teridentifikasi di daerah aliran sungai yang tercemar. Dengan adanya berbagai dampak kesehatan ini perrlu dilakukan upaya promosi kesehatan untuk meningkatkan perilaku hidup bersih dan sehat masyarakat.

Upaya promosi kesehatan seringkali hanya terfokus pada manusianya tanpa mempertimbangkan ekosistem tempat tinggal manusia dan semua makhluk hidup di lingkungannya (Parkes \& Horwitz, 2009). Untuk meningkatkan keberhasilan upaya promosi kesehatan maka dapat dilakukan dengan mengintegrasikan konsep setting, ekosistem, air dan kesehatan melalui model promosi kesehatan ekologikal yang berfokus pada system serta perubahan dan perkembangan seluruh organisasi (Parkes \& Horwitz, 2009). Pendekatan ekologis untuk promosi kesehatan pada masyarakat di daerah aliran sungai dapat dilakukan dengan mengintegrasikan intervensi pada sifat alami dan makna air bagi manusia, lokasi air, dan aspek budaya, sosial, biofisik, dan politik dari penggunaan air di lokasi tempat tinggal masyarakat (Parkes \& Horwitz, 2009). Pendekatan terintegrasi ini dapat melibatkan berbagai sektor dan organisasi dalam masyarakat dengan menggunakan proses kemitraan antara pihak akademisi, pelayanan kesehatan dan pemerintah daerah serta organisasi kemasyarakatan lainnya (Stedman-Smith, McGovern, PedenMcAlpine, Kingery, \& Draeger, 2012).

Kemitraan antara masyarakat dan perguruan tinggi(academic-communitypartnership)merupakan pendekatan yang sudah terbukti berhasil dalam meningkatkan partisipasi masyarakat di Kabupaten Sumedang (Juniarti, Haroen, \& Yani, 2018). Penelitian Zoellner et al. (2012) juga menunjukkan bahwa dengan melibatkan masyarakat dalam perumusan penyelesaian masalah maka masyarakat akan merasa memiliki dan melaksanakannya dengan baik. Universitas Padjadjaran adalah salah satu insitusi perguruan tinggi yang mempunyai peran dalam memberikan edukasi kepada masyarakat.

Edukasi merupakan segala upaya yang direncanakan untuk mempengaruhi orang lain baik individu, kelompok atau masyarakat sehingga mereka melakukan apa yang diharapkan oleh pelaku pendidikan (Notoatmojo, 2003). Edukasi merupakan proses belajar dari tidak tahu tentang nilai menjadi tahu. Edukasi tentang lingkungan penting ditanamkan kepada masyarakat sejak dini, agar dapat tertanam didalam diri. Lingkungan yang bersih merupakan salah satu sumber belajar bagi anak. Dengan adanya lingkungan yang terjaga dapat mencerminkan hidup yang sehat. Kebersihan lingkungan dimulai dari lingkungan yang paling dekat dengan kita yaitu lingkungan ruangan yang selalu kita gunakan untuk melakukan aktivitas. Kemudian setelah itu kebersihan halaman, selokan dan membersihkan jalan dari sampah.

Salah satu dampak dari lingkungan yang tidak terjaga adalah terjadinya banjir. Kecamatan Rancaekek merupakan salah satu wilayah yang rawan banjir. Banyaknya limbah pabrik dan domestik memicu terjadinya banjir. Sampah-sampah yang tersumbat mengakibatkan tingginya intensitas air di kawasan DAS Citarum. Desa Cangkuang lahan hijau sudah beralih menjadi perumahan dan pabrik yang mengakibatkan lahan untuk pembuangan sampah berkurang dan juga minim lahan pembuangan sampah. Terdapat juga beberapa warga yang membuang sampah ke sungai. Kegiatan Cilung Kangpisman dilakukan dengan cara memberi materi kepadaanak-anak TPA mengenai kebersihan danjuga mencontohkan beberapa hal yang berkaitan dengan pola hidup sehat salah satunya membuang sampah ketempat sampah, memilah sampah yang kering dan basah dan juga memberikan arahan bagaimana memisahkan sampah organik dan anorganik.

Kang Pisman merupakan gerakan di Kota Bandung kolaborasi antara pemerintah, warga, swasta dan lainnya dalam membangun peradaban baru, pengolahan sampah yang lebih maju melalui upaya Kang (Kurangi) Pis (Pisahkan) Man (Manfaatkan). Meskipun Kang Pisman merupakan program pemerintah Kota Bandung namun tim penulis ingin menedukasi anak-anak desa cangkuang tentang program tersebut. Tujuan dari pengabdian ini adalah memberikan edukasi yang diperlukan kepada anak-anak sejak dini desa cangkuang mengenai pentingnya kebersihan dan cinta lingkungan.

\section{METODE}

Kegiatan yang dilaksanakan adalah edukasi dengan tema tentang edukasi mengenai cinta lingkungan bersama Kang Pisman dengan cara 
mewarnai gambar lingkungan, dan memberikan contoh cinta lingkungan kepada anak-anak TPA AlHidayah Desa Cangkuang Kecamatan Rancaekek Kabuputen Bandung Jawa Barat. Kegiatan pertama yaitu dilakukannya pre test menggunakan flashcard berupa gambar perilaku baik dan buruk tentang sampah. Lalu dilanjutkan dengan penyampaian materi yang dilakukan oleh mahasiswa KKN tentang CILUNG KANGPISMAN (Cintai Lingkungan dengan Kurangi, Pisahkan dan Manfaatkan), pemanfaatan sampah dan perilaku baik dan buruk tentang sampah. Selanjutnya dilakukan kegiatan mewarnai gambar tentang lingkungan yang bersih. Kegiatan Cilung Kangpisman dilakukan dengan cara memberi materi kepada anak-anak TPA mengenai kebersihan dan juga mencontohkan beberapa hal yang berkaitan dengan pola hidup sehat salah satunya membuang sampah ketempat sampah, memilah sampah yang kering dan basah dan juga memberikan arahan bagaimana memisahkan sampah organik dan anorganik. Kemudian dilakukan post test dengan menggunakan flashcard berupa gambar perilaku baik dan buruk tentang sampah. Lalu dilakukan tanya jawab kepada anak-anak untuk mengetahui sejauh mana materi dapat tersampaikan.

\section{HASIL DAN PEMBAHASAN}

Sesuai dengan tujuan dilakukannya kegiatan ini, hasil capaian dari kegiatan yang dilakukan yaitu anak-anak mengetahui pentingnya kebersihan dan cinta lingkungan sejak dini. Peserta yang mengikuti kegiatan ini adalah anak anak TPA yang tinggal di lingkungan Desa Cangkuang, yaitu sebanyak 30 anak. Semua anak dapat mengikuti dengan baik kegiatan yang telah diselenggarakan oleh Tim Pengabdian. Sebelum dilakukan Pendidikan Kesehatan, peserta diberikan pre test berupa gambar tentang sampah. Tim pengabdian menanyakan apakah gambar tersebut baik dilakukan atau tidak. Post test yang dilakukan berupa gambar yang kegiatan yang baik dalam menjaga lingkungan.

Pendidikan Kesehatan berupa CILUNG KANGPISMAN (Cintai Lingkungan dengan Kurangi, Pisahkan dan Manfaatkan). Isi dari Pendidikan Kesehatan adalah pemanfaatan sampah dan perilaku baik dan buruk tentang sampah. Pemanfaatan sampah dengan cara Kurangi, Pisahkan dan Manfaatkan. Tindakan Kurangi dengan cara memilah sampah yang akan dibuang, kemudian dipisahkan sesuai dengan organic dan anorganik, setelah itu beberapa sampah yang bisa dimanfaatkan bisa dijadikan barang yang bermanfaat.

Permasalahan-permasalahan yang terjadi pada DesaCangkuang adalahbuang sampahyang tidak pada tempatnya, belum ada pemilahan sampah, sehingga menimbulkan dampak banjir. Permasalahan tersebut belum teratasi sepenuhnya sehingga menjadikan sungai lumpuh dan tidak dapat digunakan oleh masyarakat sekitar bahkan kerugian menjadi dampak utama bagi masyarakat yang tinggal di sepanjang sungai Citarum. Kerugian yang berdampak pada masyarakat tersebut yaitu karena air yang kotor dan tidak dapat digunakan dan mudah menimbulkan penyakit. Masalah kesehatan yang timbul akibat dari permaslahan tersebut yaitu berkembangnya bermacam-macam vektor penyakit seperti moluska dan insekta yang dapat menyebabkan berbagai penyakit seperti penyakit kulit, demam berdarah dan diare atau dikenal dengan water borne disease.

Water borne disease merupakan penyakit yang ditularkan ke manusia akibat adanya cemaran baik berupa mikroorganisme ataupun zat pada air. Kerugian akibat water-borne diseaseterjadi pada manusia dan juga berdampak pada lingkungan tempat manusia tinggal. Kontaminasi pada manusia dapat melalui kegiatan minum, mandi, mencuci, proses menyiapkan makanan, ataupun memakan makanan yang telah terkontaminasi saat proses penyiapan makanan (Triyono, 2014).

Data WHO menunjukkan bahwa waterborne disease merupakan penyebab India berada di peringkat pertama tentang perilaku Buang Air Besar yang sembarangan sedangkan Indonesia menduduki peringkat kedua pada tahun 2014. Data UNICEF tahun 2014 menyatakan bahwa sebanyak $44,5 \%$ dari total seluruh penduduk Indonesia masih belum memiliki akses pembuangan tinja yang layak dan 63 juta masyarakat Indonesia masih buang air besar sembarangan atau $24 \%$ dari total penduduk Indonesia masih melakukan buang air besar (BAB) sembarangan. UNICEF juga menyatakan bahwa sanitasi dan perilaku kebersihan yang buruk, serta minum air yang tidak aman berkontribusi terhadap $88 \%$ kematian anak akibat diare diseluruh dunia (Triyono, 2014).

Menurut penelitian yang dilakukan Hilmi (2002) tentang beban pencemaran limbah domestik dan pertanian di DAS Citarum Hulu, pendekatan yang harus dilakukan untuk pengelolaan limbah untuk mengurangi terjadinya degradasi kualitas dan kuantitas air, perlu dilakukan beberapa pengelolaan baik secara teknis maupun non teknis (peraturan dan kelembagaan). Adapun yang perlu dilakukan secara teknis yaitu dnegan mewajibkan penggunaan septik tank bagi setiap rumah yang persyaratannya dimasukan dalam ijin mendirikan bangunan. Apabila kelompok masyarakat tidak mampu, dibuatkan sarana pengolahan limbah/pembuatan MCK yang dilengkapi dengan pengolahan limbah cair domestik di setiap wilayah kota yang padat penduduk untuk memperkecil beban limbah yang masuk ke sungai Citarum beserta anak sungainya. 
Penelitian yang dilakukan Hafizi (2016) tentang pola pemberdayaan masyarakat di hulu sub daerah aliran sungai MIU di Sulawesi Tengah menyatakan pola pemberdayaan masyarakat yang dilakukan yaitu untuk meningkatkan kemandirian dan menswadayakan masyarakat agar mampu membuat sebuah perubahan yang bertujuan untuk meningkatkan kualitas potensi daerah. Pola pemberdayaan masyarakat dilakukan di wilayah sungai secara seimbang mencakup pengelolaan usaha berbasis sumber daya yang efisien, pemanfaatan dan rehabilitasi untuk menjaga kelestarian sungai, pelestarian nilai budaya dan kearifan lokal dan memberikan akses kepada masyarakat dalam pengelolaan kawasan sungai.

Bentuk kegiatan pemberdayaan yang dilakukan dengan memberikan pembinaan, pelatihan, pendampingan dan sosialisasi kepada masyarakat dalam upaya membentuk kelompok peduli sungai melalui kegiatan teknis maupun non teknis. Manfaat kegiatan pemberdayaan yaitu untuk memenuhi kebutuhan akan adanya panduan dalam pengembangan, untuk menghasilkan peningkatan kemampuan lembaga dalam pengelolaan lembaga secara tunggal maupun kolektif serta mendorong untuk memiliki kekuatan dalam menghadapi dan berinteraksi dengan pihak lainnya dalam peningkatan pola hidup sehat masyarakat sekitar wilayah sungai.

\section{SIMPULAN}

Kegiatan pengabdian bertujuan memberikan edukasi yang diperlukan kepada anak-anak sejak dini desa cangkuang mengenai pentingnya kebersihan dan cinta lingkungan. Kegiatan CILUNG KANGPISMAN (Cintai Lingkungan dengan Kurangi, Pisahkan dan Manfaatkan), pemanfaatan sampah dan perilaku baik dan buruk tentang sampah berlagsung dengan lancar. Implikasi dari pengabdian adalah dengan adanya edukasi tentang Kang Pisman, anak-anak dapat mengetahui pentingnya kebersihan dan cinta lingkungan sejak dini. Selain itu, anak-anak dapat menyampaikan edukasi yang didapat untuk diberitahukan ke orang tua dan keluarga terdekat.

\section{UCAPAN TERIMAKASIH}

Ucapan terimakasih diberikan kepada Rektor, Direktur Riset dan Pengabdian Masyarakat Universitas Padjadjaran.

\section{DAFTAR PUSTAKA}

Badan Litbang Kesehatan. (2013). Riskesdas 2013. Jakarta: Kementerian Kesehatan RI

Badan Litbang Kesehatan. (2018). Riskesdas 2018.
Jakarta: Kementerian Kesehatan RI

Braun, V., \& Clarke, V. (2006). Using thematic analysis in psychology. Qualitative Research in Psychology, 3(2), 77-101.

Cita Citarum. (2014). Fakta Citarum. Retrieved from http://citarum.org/tentang-kami/faktacitarum.html

Frenk, J. (2009). Reinventing primary health care: The need for systems integration. The Lancet, 374(9684), 170-173. doi:http://dx.doi. org/10.1016/S0140-6736(09)60693-0

Frenk, J., Chen, L., Bhutta, Z. A., Cohen, J., Crisp, N., Evans, T., . . Kelley, P. (2010). Health professionals for a new century: Transforming education to strengthen health systems in an interdependent world. The Lancet, 376(9756), 1923-1958.

Halder, J. N., \& Islam, M. N. (2015). Water pollution and its impact on the human health. Journal of Environment and Human, 2(1), 36-46.

Juniarti, N., Haroen, H., \& Yani, D. J. I. J. o. I. C. (2018). The Impact of Engaging People and Students in the Rural Community and Family Health Nursing Care. 18(s1).

Keleher, H., \& Parker, R. (2013). Health promotion by primary care nurses in Australian general practice. Collegian, 20(4), 215-221.

Kementerian Kesehatan RI. (2011). Pedoman Pembinaan Perilaku Hidup Bersih dan Sehat. Jakarta: Kementerian Kesehatan RI

Litbangkes, B. (2007). Laporan Hasil Riset Kesehatan Dasar (Riskesdas) Nasional 2007. Jakarta: Kementerian Kesehatan RI

Parkes, M. W., \& Horwitz, P. (2009). Water, ecology and health: ecosystems as settings for promoting health and sustainability. Health Promotion International, 24(1), 94-102.

Samba, S. (2012). Nursing Center: Konsep \& Aplikasi (Second ed.). Jakarta: Penerbit Buku Kedokteran EGC.

Stedman-Smith, M., McGovern, P. M., PedenMcAlpine, C. J., Kingery, L. R., \& Draeger, K. J. (2012). Photovoice in the Red River Basin of the north: A systematic evaluation of a community-academic partnership. Health Promotion Practice, 13(5), 599-607.

Stedman-Smith, M., McGovern, P. M., PedenMcAlpine, C. J., Kingery, L. R., Draeger, K. J. J. O. J. o. R. N., \& Care, H. (2012). Mothers' Concerns about Children's Exposure to 
Pesticide Drift in the Red River Basin of the North: A Novel Application of Photovoice. 12(2), 88-101.

Walley, J., Lawn, J. E., Tinker, A., de Francisco, A., Chopra, M., Rudan, I., . . B Black, R. E. (2008). Primary health care: Making AlmaAta a reality. The Lancet, 372(9642), 10011007. doi:http://dx.doi.org/10.1016/S01406736(08)61409-9

Watson, D., Broemeling, A.-M., Reid, R. J., \& Black, C. (2004). A results-based logic model for primary health care : laying an evidencebased foundation to guide performance measurement, monitoring and evaluation.
WHO. (2008). The World Health Report 2008: Primary Health Care (Now More than Ever). Retrieved from Geneva, Switzerland:

WHO. (2015). WHO Global Strategy on Peoplecentred and Integrated Health Services: Interim Report. Retrieved from Geneva, Switzerland:

Widyasari, W. J. J. P. L. S. (2017). Faktor Determinan Partisipasi Masyarakat Dalam Gerakan Citarum Bestari Terhadap Perilaku Masyarakat Bersih Lingkungan (Study Deskriptif Di Desa Sangkanhurip Kecamatan Katapang Kabupaten Bandung). 13(2). 